\title{
GAMBARAN SELF CONTROL SISWA PELANGGAR TATA TERTIB SEKOLAH DI SMA NEGERI 1 LUBAI
}

\author{
Deni Pranata ${ }^{1}$, Muhammad Ferdiansyah ${ }^{2}$, Syska Purnama Sari ${ }^{3}$ \\ Universitas PGRI Palembang ${ }^{1}$ \\ Email: denipranata2911@gmail.com \\ Universitas PGRI Palembang ${ }^{2}$ \\ Email: mferdiansyah34@gmail.com \\ Universitas PGRI Palembang ${ }^{3}$ \\ Email: syskapurnamasari@gmail.com
}

\begin{abstract}
ABSTRAK
Tujuan penelitian ini untukmengetahui seberapa besar persentase gambaran self control siswa pelanggar tata tertib sekolah di SMA Negeri 1 Lubai. Penelitian ini menggunakan metode penelitian deskriptif kuantitatif dengan teknik persentase.Populasi penelitian ini berjumlah 70 siswa kelas XI SMA Negeri 1 Lubai yang diambil dengan menggunakan teknik purposive sampling. Teknik pengumpulan data yang digunakan berupa instrumen angket kemampuan self control siswa. Analisis datanya menggunakan rumus Persentase.Hasil penelitian menunjukan bahwaself control siswa pelanggar tata tertib sekolah di SMA Negeri 1 Lubai berada yang terdiri dari 70 siswa sebagian besarmereka berada pada kategori rendah $(R)$ dengan jumlah frekuensi 54 siswa atau dapat dipersentasekan dengan nilai 77,1\%. Selanjutnya disusul pada kategori sangat rendah (SR) dengan jumlah frekuensi 10 siswa yang dapat dipersentasekan dengan nilai $14.3 \%$. Kemudian Self-control siswa berada pada kategori sedang (S) dengan jumlah frekuensi 6 siswa yang dapat dipersentasekan dengan nilai 8.6\%dan tidak ada siswa yang berada pada kotegori tinggi dan sangat tinggi. Berdasarkan data diatas maka rata-rata Self-controlsiswa Pelanggar Tata Tertib kelas XI di SMA Negeri 1 Lubai berada pada kategori rendah sehingga diharapkan bisa menjadi acuan untuk guru bimbingan dan konseling dalam memberikan program layanan bimbingan dan konseling disekolah.
\end{abstract}

Kata kunci: Self Control, Pelanggar Tata Tertib.

\section{DESCRIPTION OF SELF CONTROL STUDENT VIOLATIONS OF SCHOOL RULES AT SMA NEGERI 1 LUBAI}

\begin{abstract}
This study aims to determine how much the percentage of the self-control picture of students who violate school rules in SMA Negeri 1 Lubai. This study used a quantitative descriptive research method with percentage techniques. The population of this study was 70 students of class XI SMA Negeri 1 Lubai who were taken using purposive sampling technique. The data collection technique used was a questionnaire instrument of students' self-control abilities. The data
\end{abstract}


analysis used the Percentage formula. The results showed that the self-control students who violated the school discipline at SMA Negeri 1 Lubai were 70 students, most of whom were in the low category $(R)$ with a total frequency of 54 students or could be a percentage of 77, 1\%. Then followed by the very low category (SR) with a total frequency of 10 students which can be compared with a value of $14.3 \%$. Then the student self-control is in the medium category $(S)$ with a total frequency of 6 students which can be compared to a value of $8.6 \%$ and no student is in the high and very high category. Based on the data above, the average self-control of students who violate the Rules of Conduct of class XI at SMA Negeri 1 Lubai is in the low category so that it is expected to be a reference for guidance and counseling teachers in providing guidance and counseling service programs at school.

\section{Keywords: Self Control, Code Breakers.}

\section{PENDAHULUAN}

Masa remaja dihadapkan dengan banyak perubahan, diantaranya perubahan yang harus dihadapi oleh remaja yaitu perubahan fisik biologis, psikologis dan sosial. Proses perubahan tersebut bisa berdampak negatif maupun posistif, jika remaja bisa menghadapi perubahan itu dengan baik maka akan berdampak positif sebaliknya apabila remaja tidak bisa melewati perubahan tersebut maka akan berdampak negatif. Sehingga akan menimbulkan penyimpang-penyimpang baik itu merugikan orang lain maupun diri sendiri. Penyimpangan-penyimpangan yang dilakukan lebih dikenal dengan kenakalan remaja.

Istilah penyebutan kenakalan remaja dalam psikologi yaitu juvenile deliquency, yang berarti perilaku jahat.Menurut simajuntak (dalam Jamaludin 2016:118) Perilaku jahat atau kenakalan remaja merupakan gejala sakit (pantologis) secara sosial pada anak-anak remaja yang disebabimbingan dan konselingan oleh satu bentuk pengabdian sosial sehingga mereka mengembangkan bentuk tingkah laku yang menyimpang. Selanjutnya kenakalan remaja juga bisa diartikan sebagai suatu perbuatan yang dilakukan tidak sesuai dengan norma -norma yang berlaku dilingkungan masyarakat, sekolah dan keluarga. Perkelahian disekolah, membolos, terlambat kesekolah, pencurian, pembentukan geng yang bisa menimbulkan keresahan serta pelanggaran pada tata tertib disekolah 
Kenakalan remaja pada umumnya terjadi disekolah adalah pelanggaran tata tertib.Tata tertib adalah susunan ketentuan peraturan yang harus ditaati oleh seluruh siswa atau warga sekolah dan terdapat sanksi bagi yang melanggar peraturan (Putra, 2019:110).Sedangkan menurut Berutu et al (2018:77) tata tertib merupakan salah-satu pedoman atau patokan seluruh siswa agar terciptanya kenyamanan dan keamanan disekolah. Menurut Fitri dan Elisabeth (2013:135) Pelanggaran tata tertib sekolah adalah suatu tindakan yang bertentangan dengan peraturan dan pedoman sekolah yang dapat menyebabkan terganggunya keamanan serta ketertirtiban disekolah

Dari beberapa pendapat diatas dapat disimpulkan bahwa pelanggaran tata tertib adalah suatu tindakan yang bertentangan dengan peraturan-peraturan disekolah yang dapat menganggu ketentraman, keamanan serta ketertiban sekolah

\section{LANDASAN TEORI}

Pelanggaran tata tertib disekolah diduga karena kurangnya self control (kontrol diri) serta ketidakmampuan dalam mengembangkan self control. Rendahnya self control sesorang dapat menimbulkan perilaku negatif dan akan berakibat pada pelanggaran tata tertib sekolah. Sebaliknya apabila seseorang memiliki self control yang tinggi, maka seseorang itu akan membatasi perilakunya karena memikirkan dampak serta akibat dari apa yang dilakukannya. Menurut Goldfried \&Merbaum(dalam Oktarini, 2014: 9). Self control adalah sebagai suatu kemampuan untuk menyusun, membimbing, mengatur, dan mengarahkan bentuk perilaku yang dapat membawa individu ke arah konsekuensi positif. Kurangnya self control dapat dilihat dari sikap dan perilaku penyimpangan atau kenakalan yang remaja lakukan serta pelanggaran tata tertib sekolah .Maraknya kasus yang melibatkan sikap dan perilaku yang menyimpang tidak sesuai lagi dengan nilai dan norma-norma yang berlaku.

Dari beberapa teori dan pendapat diatas dapat disimpulkan bahwa Self Control adalah suatu kemampuan dalam diri seseorang yang dapat membimbing, mengarahkdsan, membatasi, Mengendalikan pikiran dalam pengambilan keputusan tindakan dan berperilaku yang dijadikan sebagai acuan yang dapat 
membawanya ke sikap yang postif dan lebih membatasi perilaku yang menyimpang sehingga apa yang dilakukan sesuai dengan ketentuan yang berlaku

Oleh karena itu, kemampuan self control menjadi hal yang sangat mendasar dan penting dimiliki oleh remaja agar mampu menumbuhkan kepribadian dan sikap yang positif. Hasil penelitian yang dilakukan oleh Husna (2019:60) dengan judul "tingkat kontroldiri siswa dalam mematuhi tata tertib sekolah di SMA 1 Canduang" ditemukan fenomena di SMA 1 Canduang ada beberapa siswa yang melanggar tata tertib sekolah seperti membolos saat jam pelajaran, pergi kekantin dan duduk diluar kelas pada saat pergantian jam pelajaran, terlambat datang kesekolah tidak memakai atribut dengan lengkap, memakai baju tidak rapi dan baju dikeluarkan. Pelanggaran tata tertib tersebut dikarenakan kurang self control pada diri siswanya.Fenomena serupa juga terjadi di SMA Negeri 1 Lubai.Pelanggaran tata tertib yang sering ditemukan.

Berdasarkan dari hasil wawancara dengan guru bimbingan dan konseling dan Observasi yang dilakukan peneliti di SMA Negeri 1 Lubai ditemukan beberapa kenakalan remaja yang melanggar tata tertib sekolah diantaranya ada beberapa siswa yang rambutnya panjang dan baju dikeluarkan, tidak memakai atribut seragam dengan lengkap seperti tidak memakai ikat pinggang, lambang sekolah dibaju, sering ribut dan membuat kegaduhan dikelas sehingga kelas yang disebelah terganggu. Serta ketika tadarus alquran dipagi hari banyak yang masih sibuk masing-masing seperti bermain handpone, piket kelas, mengerjakan PR dikelas. Ketika waktu jam istrahat selesai masih banyak yang dikantin. Bermain handpone saat pelajaran berlangsung. Hal tersebut diduga karena self control yang dimiliki para siswa di SMA Negeri 1 Lubai rendah sehingga pelanggaran tata tertib sekolah bisa terjadi.

Sejalan dengan itu sekolah adalah wadah dalam pembentukan karakter dan perilaku yang baik serta mencetak generasi penerus bangsa.Maka dengan itu perlunya suatu penanganan khusus dalam permasalahan yang terjadi di SMA Negeri 1 Lubai. Tugas dan peran dalam hal ini adalah guru bimbingan dan konseling, disini guru bimbingan dan konseling diharapkan dapat membantu siswa dalam menyelesaikan permasalahnya yang diduga karena rendahnya self 
control siswa SMA Negeri 1 Lubai. Dalam menjalankan tugasnya maka guru bimbingan dan konseling memerlukan layanan yang tepat dalam pelaksaan pelayanan bimbingan dan konseling

\section{METODE PENELITIAN}

Jenis penelitian ini menggunakan metode deskriptif dengan pendekatan kuantitatif dalam penelitian ini memberikan gambaran keadaan masa sekarang. Hal ini juga dikemukakan oleh Lechmann dalam Yusuf (2014:62) penelitian deskriptif kuantitatif adalah salah satu jenis penelitian yang bertujuan mendeskripsikan secara sistematis, faktual dan akurat mengenai fakta dan sifat populasi tertentu atau mencoba mengambarkan fenomena secara detail. Dengan demikian dapat disimpulkan bahwa penelitian deskriptif kuantitatif adalah data yang diperoleh dari sampel dan populasi dianalisis sesuai dengan metode statistik yang digunakan. Penelitian ini juga bermaksud untuk mendapatkan gambaran tentang pengendalian diri siswa pelanggar tata tertib

Teknik yang digunakan dalam pengambilan sampel pada penelitian ini adalah peneliti menggunakan teknik purposive sampling. Teknik pengambilan sampel menggunakan teknik purposive sampling, dilakukan karena sesuai dengan kriteria tertentu yaitu siswa dan siswi yang sering membuat kegaduhan dikelas, memakai atribut tidak lengakap dan sering bermain handhpone dikelas, Jadi sampel dalam penelitian ini adalah seluruh siswa kelas XI IIS di SMA Negeri 1 Lubai yang berjumlah 70 siswa.

Untuk kriteria pencapaian tingkat Selfcontrol siswa pada aspek Selfcontrol, di mana pada aspek kontrol perilaku terdapat 10 item/butir pernyataan, aspek kontrol kognitif terdapat 10 item/butir pernyataan, dan pada aspek kontrol pengambilan keputusan terdapat $10 \mathrm{item} / \mathrm{butir}$ pernyataan.

\section{HASIL PENELITIAN DAN PEMBAHASAN HASIL PENELITIAN}

Data dalam penelitian ini berupa hasil angket tingkat self controlpelanggar tata tertib sekolah di SMA Negeri 1 Lubai.Apabila ditampilkan dalam bentuk 
distribusi frekuensi, tingkat Self-control siswa pelaku pelanggar tata tertib sekolah di SMA Negeri 1 Lubai tabel 1 sebagai berikut:

Tabel 1. Distribusi Frekuensi Tingkat Pengendalian Diri Siswa Pelaku Agresif Verbal

\begin{tabular}{|c|c|c|c|c|}
\hline No & Interval & Kategori & Frekuensi & Persentase (\%) \\
\hline 1 & 107 s.d 135 & Sangat Tinggi (ST) & 0 & 0 \\
\hline 2 & 91 s.d 106 & Tinggi (T) & 0 & 0 \\
\hline 3 & 73 s.d 90 & Sedang $(\mathrm{S})$ & 6 & 8.6 \\
\hline 4 & 55 s.d 72 & Rendah (R) & 54 & 77,1 \\
\hline 5 & $\leq 54$ & Sangat Rendah (SR) & 10 & 14.3 \\
\hline \multicolumn{3}{|c|}{ Jumlah } & 36 & 100 \\
\hline
\end{tabular}

Berdasarkan tabel 4.2 dan gambar 1 terlihat bahwa dari jumlah keseluruhan sampel yang berjumlah 70 siswa, sebagian besar Self-control mereka berada pada kategori rendah $(\mathrm{R})$ dengan jumlah frekuensi 54 siswa atau dapat dipersentasekan dengan nilai 77,1\%. Selanjutnya disusul pada kategori sangat rendah (SR) dengan jumlah frekuensi 10 siswa yang dapat dipersentasekan dengan nilai $14.3 \%$. Kemudian Self-control siswa berada pada kategori sedang (S) dengan jumlah frekuensi 6 siswa yang dapat dipersentasekan dengan nilai 8.6\% dan tidak ada siswa yang berada pada kotegori tinggi dan sangat tinggi. Berdasarkan data diatas maka Selfcontrol siswa pelanggar tata tertib sekolah pada kategori rendah.Ini dapat diartikan dan disimpulkan bahawa siswa belum mampu untuk mengatur pelaksanaan dan stimulus, belum mampu melihat yang tidak menyenangkan dari segi positif, belum mampu menilai situasi secara positif dengan subyektif, belum mampu mengambil tindakan positif dari sebuah permasalahan dan belum mampu mengambil keputusan secara matang. Selanjutnya secara rinci deskripsi Selfcontrol siswa berdasarkan aspeknya dapat dilihat dalam tabel berikut: 
Tabel 2. Deskripsi Rata-rata (Mean) dan Persentase (\%) Tingkat

Pengendalian Diri Siswa Pelaku Agresif Verbal Berdasarkan Aspeknya

\begin{tabular}{|c|c|c|c|c|c|c|c|c|c|}
\hline \multirow[b]{2}{*}{ No } & \multirow[b]{2}{*}{ Aspek } & \multicolumn{7}{|c|}{ Skor } & \multirow[b]{2}{*}{ Ket } \\
\hline & & Ideal & Tertinggi & Terendah & Total & $\begin{array}{r}\text { Rata } \\
\text {-Rata }\end{array}$ & Sd & $\%$ & \\
\hline 1 & $\begin{array}{l}\text { Perilaku } \\
\text { (8) }\end{array}$ & 40 & 33 & 10 & 1407 & 20,92 & 3,85 & 52,3 & $\mathrm{R}$ \\
\hline 2 & $\begin{array}{c}\text { Kognitif } \\
\text { (9) }\end{array}$ & 45 & 30 & 12 & 1472 & 22,27 & 3,97 & 49,48 & $\mathrm{R}$ \\
\hline 3 & $\begin{array}{c}\text { Pengambilan } \\
\text { Keputusan } \\
\text { (10) }\end{array}$ & 50 & 34 & 14 & 1678 & 23,97 & 4,05 & 47,94 & $\mathrm{R}$ \\
\hline & $\begin{array}{l}\text { eseluruhan } \\
\text { (27) }\end{array}$ & 135 & 97 & 36 & 4557 & 67,16 & 11,87 & 49,74 & $\mathbf{R}$ \\
\hline
\end{tabular}

Berdasarkan tabel 2, terlihat bahwa tingkat Selfcontrol diri siswa pada aspek indikator berada pada kategori rendah (R) dengan keseluruhan skor tertinggi yang dicapai sebesar 97 dari skor ideal yaitu 135. Skor terendah keseluruhan adalah 36, skor total mencapai 4557, rata-rata skor 67,16 dengan tingkat capaian keseluruhan responden 49,74\% sehingga dapat diinterpretasikan dalam kategori rendah (R) dengan standar deviasi berada pada nilai 11,87.

Selanjutnya secara rinci dari hasil analisis data tampak bahwa skor tertinggi rata-rata Self-control terletak pada aspek perilaku dengan rata-rata skor 20,92 atau dapat dipersentasekan dengan nilai 52,3\%, ini menunjukkan bahwa siswa masih perlu bimbingan dan pengembangan dalam mengatur aspek perilakunya karena terlihat bahwa siswa belum mampu utnuk mengatur pelaksanaan dan stimulus serta belum mampu melihat yang tidak menyenangkan dari segi positif. Kemudian skor rata-rata terendah terdapat pada aspek pengambilan keputusan dengan nilai persentase sebesar 47,94\%. Namun demikian nilai tersebut masih dapat diinterpretasikan dalam kriteria kategori rendah.Ini menunjukkan bahwa siswa 
perlu peningkatan lagi dalam mengambil tindakan positif dari sebuah permasalahan dan mengambil keputusan secara matang.

\section{PEMBAHASAN}

Hasil penelitian menunjukan aspek yang dominan dalam tingkat pengendalian diri siswa berada adalah aspek kontrol perilaku yaitu sebesar 52,3\%. Menurut Averill (dalam Ghufron \& Risnawati S, 2017 : 29) Kemampuan mengontrol perilaku ini diperinci menjadi dua indikator, yaitu mengatur pelaksanaan (regulated administration) dan kemampuan memodifikasi stimulus (stimulus modifiability). Kemampuan mengatur pelaksanaan merupakan kemampuan untuk menentukan siapa yang mengendalikan situasi atau keadaan, dirinya sendiri atau sesuatu diluar dirinya. Individu yang kemampuan Self Control nya baik akan mampu mengatur perilaku dengan menggunakan kemampuan dirinya dan bila tidak mampu individu akan menggunakan sumber eksternal. Kemampuan mengatur stimulus merupakan kemampuan untuk mengetahui bagaimana dan kapan suatu stimulus yang tidak dikehendaki dihadapi. Ada beberapa cara yang digunakan, yaitu mencegah atau menjauhi stimulus, menempatkan tenggang waktu di antara rangkaian stimulus yang sedang berlangsung, menghentikan stimulus sebelum waktunya berakhir, dan membatasi intensitasnya.

Hasil penelitian menunjukan tingkat self control pada aspek kontrol kognitif yaitu sebesar 49,48\%. Menurut Averill (dalam Ghufron \& Risnawati S, 2017 : 29) Merupakan kemampuan individu dalam mengelola informasi yang tidak diinginkan dengan cara menginterpretasi, menilai, atau menggabungkan suatu kejadian dalam suatu kerangka kognitif sebagai adaptasi psikologis atau untuk mengurangi tekanan. Sebuah informasi yang dimiliki oleh individu mengenai suatu keadaan yang tidak menyenangkan, individu dapat mengantisipasi keadaan tersebut dengan berbagai pertimbangan. Melakukan penilaian berarti individu berusaha menilai dan menafsirkan suatu keadaan atau peristiwa dengan cara memperhatikan segi-segi positif secara subjektif.

Selanjutnya hasil penelitian menunjukan tingkat self control pada aspek kontrol pengambilan keputusan yaitu sebesar 47,94\%. Menurut Averill (dalam Ghufron 
\& Risnawati S, 2017 : 29) Merupakan kemampuan seseorang untuk memilih hasil atau suatu tindakan berdasarkan pada sesuatu yang diyakini atau disetujuinya. Kendali diri dalam menentukan pilihan akan berfungsi baik dengan adanya suatu kesempatan, kebebasan, atau kemungkinan.. Siswa yang memiliki kontrol diri yang tinggi akan mampu menginterprestasikan setiap stimulus yang diberikan, mempertimbangkannya dan memilih tindakan yang akan dilakukan dengan meminimalkan konsekuensi atau dampak yang tidak diinginkan. Sebaliknya, dengan siswa yang memiliki kontrol diri yang rendah, mereka akan kesulitan dalam mengarahkan dan mengatur perilaku sehingga mereka akan cenderung menunda tuntutan tugas sebagai siswa dan mengalihkannya kepada kegiatan yang lebih menyenangkan.

Sekarang ini hampir seluruh lembaga pendidikan sudah memiliki guru pembimbing dan konseling di sekolah.Usaha ini dilakukan karena guru pembimbing dipandang sebagai salah satu unsur yang dapat membantuproses pendidikan.Di samping itu telah banyak contoh yang menunjukan bahwa keberadaan guru pembimbing dapat lebih intensif untuk mengangani siswa-siswa yang bermasalah. Berperan penting untuk membina sikap murid di sekolah, dari sekian banyak guru bidang studi, guru BK lah yang sangat terpenting yang dimana seorang guru BK memberikan pemahaman kepada klien, agar klien mampu mengatasi masalah yang dihadapi, mengadakan perubahan tingkah laku positif, melakukan pemecahan masalah, melakukan pengambilan keputusan yang sesuai dan tidak melanggar peraturan. Guru BK berperan dalam berbagai upaya untuk mengungkapkan masalah yang dihadapi bagi siswa yang memiliki masalah dalam belajar terkait dengan mengembangkan.

\section{KESIMPULAN}

Berdasarkan hasil analisis data, deskripsi, pengujian hasil penelitian, dan pembahasan, dapat diambil kesimpulan bahwa gambaran self control siswa pelanggar tata tertib sekolah di SMA Negeri 1 Lubai yang terdiri dari 70 siswa sebagian besar Self-control mereka berada pada kategori rendah (R) dengan jumlah frekuensi 54 siswa atau dapat dipersentasekan dengan nilai 77,1\%. 
Selanjutnya disusul pada kategori sangat rendah (SR) dengan jumlah frekuensi 10 siswa yang dapat dipersentasekan dengan nilai $14.3 \%$. Kemudian Self-control siswa berada pada kategori sedang (S) dengan jumlah frekuensi 6 siswa yang dapat dipersentasekan dengan nilai $8.6 \%$ dan tidak ada siswa yang berada pada kotegori tinggi dan sangat tinggi. Berdasarkan data diatas maka Self-control siswa Pelanggar Tata Tertib kelas X di SMA Negeri 1 Lubai berada pada kategori rendah. . Ini dapat diartikan dan disimpulkan bahawa siswa belum mampu untuk mengatur pelaksanaan dan stimulus, belum mampu melihat yang tidak menyenangkan dari segi positif, belum mampu menilai situasi secara positif dengan subyektif, belum mampu mengambil tindakan positif dari sebuah permasalahan dan belum mampu mengambil keputusan secara matang.

\section{DAFTAR PUSTAKA}

Arikunto, \& Suharsimi. 2010. Prosedur Penelitian. Jakarta: Rineka Cipta.

Berutu, E., \& et al. 2018. Implementasi Tata Tertib Sekolah Dalam Membentuk Kedisiplinan Siswa Sekolah Negeri Gajah Aceh Besar. Jurnal Ilmiah Pendidikan Pendidikan Guru Sekolah Dasar, Vol 3 No 2.

Fitri, L., \& Elisabeth, C. S. 2013. Penerapan Layanan Informasi Tentang Etika Dan Displin Sekolah Untuk Menggurangi Pelanggaran Tata Tertib Pada Siswa SMP. Jurnal Bimbingan Dan Konseling, Vol 1 No 1

Gufron, M., \& Rini, R. 2017. Teori-Teori Psikologi. Yogyakarta: Ar-Ruzz Media.

Husna. 2019. Tingkat Kontrol Diri Siswa Dalam Mematuhi Tata Tertib Sekolah Di SMA N 1 Canduang. Vol 8 No 1.

Jamaludin, A. 2016. Dasar-Dasar Pantalogi Sosial. Bandung: CV Pustaka Setia.

Mukhtar, et al. 2016. Program Layanan Bimbingan Klasikal Untuk Meningkatkan Self Control Siswa. Jurnal Psikopedagogik, Vol 5 No 1.

Putra, R et al. 2019. Penerapan Tata Tertib Sekolah Dalam Membentuk Perilaku Kedisiplinan Siswa Disekolah Dasar Negeri 2 Sedangsari Kecamatan Batuwarno Kabupaten Wonogiri Tahun Pelajaran 2019/2020. Jurnal Pendidikan, Vol 1 No 1 